\title{
Effect of E-Banking on Banking Sector of Bangladesh
}

\author{
Mohammad Shamsus Sadekin ${ }^{1, *}$, Md. Abdul Hannan Shaikh ${ }^{2}$ \\ ${ }^{1}$ Department of Humanities, Chittagong University of Engineering \& Technology, Chittagong, Bangladesh \\ ${ }^{2}$ Department of Management, Islamic University, Kushtia, Bangladesh
}

Email address:

sadekinmba@yahoo.com (M. S. Sadekin)

${ }^{*}$ Corresponding author

\section{To cite this article:}

Mohammad Shamsus Sadekin, Md. Abdul Hannan Shaikh. Effect of E-Banking on Banking Sector of Bangladesh. International Journal of Economics, Finance and Management Sciences. Vol. 4, No. 3, 2016, pp. 93-97. doi: 10.11648/j.ijefm.20160403.11

Received: March 16, 2016; Accepted: March 24, 2016; Published: April 5, 2016

\begin{abstract}
The study was designed to investigate the impact of e-banking in Bangladesh. There appears a few extensive study on e-banking practices has been conducted in Bangladesh. But no comprehensive study has yet been conducted especially on security of e-banking in Bangladesh. The main objective of present study is to find out the practice and impact of e-banking in Bangladesh. The investigation was concentrated in various divisions, districts, towns and rural areas in Bangladesh. The sample consisted of 120 bankers and bank customers, were selected purposively from various territory. For analyzing data suitable statistical tools Statistical Package for Social Science (SPSS) were used. Major findings of this study is e-banking required minimum man power than traditional banking, E-banking reduces carrying cash, Cards are used for shopping, No need to maintain huge documents for banking functions in e-banking, Customers feel insecurity from hijacker to withdraw and deposit money from ATM booths, All the ATM booths of Bangladeshi banks are not in safe position.
\end{abstract}

Keywords: E-banking, Impact, Security

\section{Introduction}

E-banking implies provision of banking products and services through electronic delivery channels. It permits anytime, anywhere and any how banking. It offers easy, faster, convenient, low cost banking services around the clock [1]. E-Banking as the wave of the future, provides enormous benefits to consumers in terms of cost of transactions, either through internet, telephone or other electronic delivery channels. E-Banking is now widely practiced in Bangladesh. There are various types of ebanking services like SMS banking, Tele Banking, Push and Pull services, ATM, Fast Track etc. that have been introduced by the commercial banks in Bangladesh [2]. E-banking product and services can include wholesale products for corporate customers as well as retail and fiduciary products for individual customers. E-banking refers to systems that enable bank customer to access accounts and general information on bank products and services through a personal computer or other intelligence device [3]. Now a day's due to emerging global economy, e-commerce and e-business have increasingly become a necessary component of business strategy and a strong catalyst for economic development. The new information technology is becoming an important factor in the future development of financial services industry, and especially banking industry. As a third-world developing country, Bangladesh is far behind to reach the expected level in global banking system [4]. Electronic banking has been around for some time in the form of automatic teller machines 1 customer transaction costing about $\$ 1$ in a traditional "brick and mortar" bank branch or $\$ 0.60$ through a phone call costs only about $\$ 0.02$ online. Electronic banking also makes it easier for customers to compare banks' services and products, can increase competition among banks, and allows banks to penetrate new markets and thus expand their geographical reach. Some even see electronic banking as an opportunity for countries with underdeveloped financial systems to leapfrog developmental stages [5]. The state owned commercial banks in Bangladesh may not be offered all the functions of e-banking. The customers may not be trusted on e-banking without providing top level of security. Many customers may be used either mobile bank account or ATM account in Bangladesh, which are not actually highly secured. [9] Some other study have done on e-banking 
system in Bangladesh such as [10], [11], [12]. But No comprehensive stud has done on effect of e-banking on banking sector in Bangladesh. Ali mentioned in his study that On-line banking can act as a complementary factor of ebusiness. Bangladesh Bank has recently argued to introduce automated clearing house system. This pushed upward transition from the manual banking system to the on-line banking system [13].

\subsection{Different Forms of Electronic Banking}

The terms 'PC banking', 'online banking', 'Internet banking', 'Telephone banking' or 'mobile banking' refer to a number of ways in which customers can access their banks without having to be physically present at the bank branch. E-banking may be understood as term that covers all these ways of banking business electronically [4], [7].

\subsubsection{Tele-banking}

Tele-banking service is provided by phone. To access an account it is required to dial a particular telephone number and there are several options of services. Options included

i. Checking account balance

ii. Funds transfer between current, savings and credit card accounts

iii. Bill payments

iv. Stock exchange transaction

v. Receive statement via fax

vi. Loan payment information

\subsubsection{PC Banking}

The increasing awareness of the importance of literacy of computer has resulted in increasing use of personal computers through the entire world. Furthermore, incredible plummet of cost of microprocessor has accelerated the use of computer. The term 'PC banking' is used for banking business transacted from a customer's PC. Using the PC banking or home banking now customers can use their personal computers at home or at their office to access their accounts for transactions by subscribing to and dialing into the banks' Intranet proprietary software system using password.

\section{Types of PC Banking}

Basically, there are two types of PC banking.

The first type is online banking, in which bank transactions are conducted within closed networks. The customer needs specialized software provided by his bank. The second type is Internet banking, which German banks have been offering since the mid-nineties, although the only product they were offering at the time was information. Unlike closed networks, Internet banking permits the customer to conduct transactions from any terminal with access to the Internet.

\section{Internet Banking}

Internet banking would free both bankers and customers of the need for proprietary software to carry on with their online banking transactions. Customer behavior is changing rapidly. Now the financial service is characterized by individuality, independence of time and place and flexibility. These facts represent huge challenges for the financial service providers. So the Internet is now considered to be a 'strategic weapon' for them to satisfy the ever-changing customers' demand and innovative business needs.

Adequate legal framework and maximum security are the two essential factors for Internet banking. The comprehensive security infrastructure includes layers of security from the network to the browser, including sophisticated encryption that protects customers' from intrusion when they access the bank over the public network.

\subsubsection{Mobile Banking}

Actually mobile banking is a variation of Internet banking. Mobile banking is a good example of how the lines between the various forms of e-banking are becoming gradually blurred. Due to the new transmission technologies such as WAP (Wireless Application Protocol), portable terminal like mobile phones, personal digital assistant (PDA) or small hand-held PCs are providing bank customers with access to the Internet and thus paving the way to Internet banking. It assures immense flexibility and makes the financial services independent of time and place. However, the use of mobile banking is still in a nascent state. The slower transmission speed of the WAP standard and the limited amount of information available are just two of the factors inhibiting the use of those terminals.

\subsection{Advantages of E-banking in Bangladesh}

There are a substantial number of educated unemployed youth forces, with ability to read and write English exist in the country. They can be trained within a required skill in a short time.

Baten and Kamil [4] mentioned the following advantages of e-banking in Bangladesh:

i. Short term Benefits: E-banking reduces extra time of making a transaction. It increases productivity and efficiency of bankers. It eliminates duplication and wastage of documents; minimize maintenance cost, shortage cost and curtail security cost.

ii. Long-term benefits: (i) Create new opportunities of jobs for unemployment people: The issue of computers eliminating jobs of people is quite emotional and painfully real. But it has two sides that automation will eliminate certain types of job like record keeper and also create jobs like administrator, system analyst, programmer, operator etc. and help to reduce unemployment problem. (ii) Participate in the country's economic health: Banks with a national economy, work towards building national capital, increasing national savings and mobilizing investments in trade and industry. (iii) Proper planning and monitoring: Proper monitoring is possible by the management in e-banking without visiting the branch. Proper use of resources will be ensured by planning and monitoring.

Advantages of e-banking can also be categorized into the following two types

a) From the banks'view point: From the bank's point of 
view the first benefits for the banks offering e-banking services is better branding and better responsiveness to the market. The other benefits are possible to measure in monetary terms. The main goal of every company is to maximize profits for its owners and banks are not any exception. As e-banking minimize operating costs of bank transactions so it will offer a perfect opportunity for maximizing profits.

b) Benefits from the customers' point of view: The main benefit from the bank customers' point of view is significant saving of time by the automation of banking services processing and introduction of an easy maintenance tools for managing customer's money. The main benefits of e-banking are as follows:

i. Increased comfort and timesaving-transactions can be made 24 hours a day, without requiring the physical interaction with the bank.

ii. Quick and continuous access to information. Corporations will have easier access to information as, they can check on multiple accounts at the click of a button.

iii. Better cash management. E-banking facilities speed up cash cycle and increases efficiency of business processes as large variety of cash management instruments is available on Internet sites of banks.

iv. Private customers seek slightly different kind of benefits from e-banking.

v. Reduced costs: This is in terms of the cost of availing and using the various banking products and services.

vi. Convenience: All the banking transactions can be performed from the comfort of the home or office or from the place a customer wants to Speed.

vii. The response of the medium is very fast; therefore customers can actually wait till the last minute before concluding a fund transfer.

viii. Fund's management. Customers can download their history of different accounts and do

ix. "what-if" analysis on their own PC before affecting any transaction on the web.

\section{Methodology of the Study}

Data for the study collected both from the secondary and primary sources. Secondary data has been collected from different books, journals, seminar paper, research reports, official reports, periodicals, survey reports, web-sites, annual reports and others. Primary data has been collected from 16 selected banks located in Dhaka, Chittagong, Rajshahi, and Khulna Division those offer e-banking facilities to their customers. Sample were selected from State Owned Com Samples of a total 120 respondents were randomly chosen. All respondents were basically of two categories; bankers and bank customers. Bankers were selected from different branches of state owned commercial banks, domestic private commercial banks and foreign commercial banks in
Bangladesh and bank customers were selected from different university, college and school teachers and students, businessmen and other professionals from private and public sectors. Two sets of questionnaires were designed and distributed to bankers and bank customers. The questionnaires were distributed directly among the respondents through email. Questions were basically two categories; i. 10 questions relating to personal profile and 12 questions were relating to the effect of e-banking on banking sector in Bangladesh. Among the respondents 44 were banker and 76 were bank customers. Data were analyzed by using SPSS software.

\section{Results and Analysis}

Followings are the presentation of the result and analysis of data collected for the study. Responses from total 120 respondents consisting of 98 male and 22 female, 34 married and 86 unmarried, and 28 from rural and 92 from urban areas selected for the study were considered.

Table 1. Service Quality of Banking Sector after Implementing E-Banking.

\begin{tabular}{|c|c|c|c|}
\hline \multicolumn{4}{|c|}{ Service Quality of Banking Sector } \\
\hline \multicolumn{2}{|c|}{ Traditional Banking } & \multicolumn{2}{|c|}{ E-Banking } \\
\hline Good & Not Good & Good & Not Good \\
\hline No. $(\%)$ & No. $(\%)$ & No. $(\%)$ & No. $(\%)$ \\
\hline & & & 49 \\
\hline$(46.67)$ & $(53.53)$ & $(59.17)$ & $(40.83)$ \\
\hline
\end{tabular}

Table 1 shows that among the respondents $53.33 \%$ said service quality of traditional banking is not good and $59.17 \%$ said service quality of e-banking is good. Service quality increased when e-banking runs their activities in banking sector in Bangladesh.

Table 2. Security Status of Banking Transaction.

\begin{tabular}{lll}
\hline \multirow{2}{*}{ Security Gap } & Yes & No \\
\cline { 2 - 3 } & $\mathbf{( \% )}$ & $\mathbf{( \% )}$ \\
\hline \multirow{2}{*}{ Traditional Banking } & 09 & 111 \\
\multirow{2}{*}{ E-Banking } & $(7.5 \%)$ & $(92.5 \%)$ \\
& 37 & 83 \\
\hline
\end{tabular}

It is obtained from Table 2 that $92.5 \%$ said traditional banking system has no security gap but $69.17 \%$ said ebanking has security gap at the time of making transaction.

Table 3. Speed Quality of Online Transactions.

\begin{tabular}{llll}
\hline $\begin{array}{l}\text { Transaction } \\
\text { Speed }\end{array}$ & $\begin{array}{l}\text { No. of } \\
\text { Respondents }\end{array}$ & Percentage & $\begin{array}{l}\text { Cumulative } \\
\text { Percentage }\end{array}$ \\
\hline Excellent & 10 & 8.3 & 8.3 \\
Good & 44 & 36.7 & 45.0 \\
Not Good & 36 & 30 & 75.0 \\
Very Bad & 4 & 3.3 & 78.3 \\
N/A & 26 & 21.7 & 100 \\
Total & 120 & 100 & \\
\hline
\end{tabular}

It is expanded from the Table 3 that among the respondents $36.7 \%$ said Speed quality of transaction is good and only $3.3 \%$ respondents said the speed quality of transaction in Bangladesh is very bad. 
Table 4. Personal Computer and Internet Connection.

\begin{tabular}{|c|c|c|c|c|}
\hline \multirow{5}{*}{$\begin{array}{l}\text { Internet Connection } \\
\text { in PC }\end{array}$} & \multicolumn{3}{|c|}{ Personal Computer In Residence } & \multirow[t]{2}{*}{ Total } \\
\hline & & Yes & No & \\
\hline & Yes & 79 & 5 & $84(70 \%)$ \\
\hline & No & 9 & 27 & $36(30 \%)$ \\
\hline & & $\begin{array}{l}88 \\
(73,33 \%)\end{array}$ & $\begin{array}{l}32 \\
(26,67 \%)\end{array}$ & $\begin{array}{l}120 \\
(100 \%)\end{array}$ \\
\hline
\end{tabular}

It is gained from Table 4 that among the respondents $73.33 \%$ have personal computer and $70 \%$ respondents use internet in their own computer. Out of the respondents $26.67 \%$ have no personal computer and $30 \%$ respondents do not use internet.

Table 5. E-service Quality of Banks in Respect of Location.

\begin{tabular}{llllll}
\hline \multirow{2}{*}{$\begin{array}{l}\text { Location of } \\
\text { Branch }\end{array}$} & \multicolumn{6}{l}{ E-service Quality of Banks in Bangladesh } \\
\cline { 2 - 6 } & $\begin{array}{l}\text { Not } \\
\text { Good }\end{array}$ & Satisfactory & $\begin{array}{l}\text { Very } \\
\text { Good }\end{array}$ & Excellent & Total \\
\hline Rural Area & 11 & 18 & 2 & 3 & 34 \\
Municipality & 16 & 14 & 7 & 3 & 40 \\
District Town & 5 & 7 & 4 & 1 & 17 \\
City Corporation & 15 & 5 & 6 & 3 & 29 \\
Total & 47 & 44 & 19 & 10 & 120 \\
\hline
\end{tabular}

Table 5 shows that among the respondents 34 live in rural area, 40 in municipalities, 17 in district towns and 29 in city corporations. Respondents who live in rural area $15 \%$ of them feel e-banking service is satisfactory in Bangladesh.

\section{Findings}

Various impacts of e-banking are obtained from present study are as follows:

i. Impact on Consumers: Various impacts are generated from e-banking to it's customers of consumer products, such as: Choosing from a variety of options such as size and color, viewing any or all of product specifications and photographs; purchases will be delivered directly to their door; ordering products without leaving their home; security knowing every transaction is secure; and checking how much they have "spent" before committing to purchase.

ii. Impact on Traders

There are high impacts are generated from e-banking to traders; such as: i) Overhead costs of an e-banking web site is generally much less than the cost of traditional banking. ii) Seller has the ability to reach customers all over the world rather than being limit to a certain geographical location iii) Increase in sales volume by taking the help of e-banking. iv) Everything is maintained through secure software so in no longer required of human intervention.

iii.Impact on Social Life

Peoples who have an online bank account, gets some extra benefits of e-banking activities. Without any cash handling risk, people get the following services from e-banking which facilitate him from many points: Railway Ticket, BRTA Payment, Bus Ticket, Airline Ticket, Airtime Purchase, Daily Deal Site, Hotel Booking, Internet Bill Payment, Education, Lifestyle Shops, Gift Item, Grocery, House Hold Products, E- shop, Book Store, Job Site etc. They can check balance through e-mail and can collect money when necessary. Almost all private commercial banks give this facility to their account holders.

Other major findings relating to impacts of e-banking are given below:

i. Speedy Transaction: It is expanded from Table 3 that internet connection in Bangladesh is good. So it will take very short time to complete a transaction by ebanking. As a result, e-banking saves important time of both customers and bankers.

ii. Avoidance Cash Handling Risk: Almost all recognized shopping center has started online shopping and services were digitalized. Customers can purchase product without carrying cash with them. ATM booths are available in all renowned markets. So without carrying any cash customers can complete their shopping credit card and debit card.

iii. Low Operating Cost: Operating costs are minimized in e-banking. E-banking requires minimum documents. So documentation, transportation and other operating costs are minimized by e-banking.

iv. Minimization of Man Power: One man can receive and pay large number of customers within very short time in e-banking, which was not possible under traditional banking.

v. Twenty Four Hours Access: Money is available 24 hours a day in e-banking. Traditional banks provide money from 10 a.m. to 3: 30 p.m. In case of emergency traditional banks unable to provide money to their customers.

vi. Avoidance of Huge Documents: All traditional banking documentations are not essential in ebanking. Only a few vouchers are maintained.

vii. Minimize Errors: As e-banking reduces documentations to make a transaction so the possibilities of mistake will be reduced in minimum limit.

viii. Reducing of Gathering in Bank: E-banking means non-branch banking. Customers can withdraw and deposit money by using ATM booths and also possible to make purchase or sale. So customers need not make gathering in bank counter.

ix. Reducing Financial Security: It is obtained from Table 3 that $30.83 \%$ respondents feel there has security gap in e-banking system weather only $7.5 \%$ of them feel same in traditional banking.

x. Increasing Unemployment Problem: Unemployment problem is a big problem in Bangladesh. Population density in Bangladesh is comparatively high than any other countries in world and employment opportunity is not enough. As e-banking minimize manpower to operate banking transactions so it is increasing unemployment problem in Bangladesh.

xi. Increasing Computer and Internet Users

It is obtained from Table 4 that e-banking users are more advance in using computer and internet than traditional 
account holders. Among the respondents $73.33 \%$ have personal computer and $70 \%$ respondents use internet in their own computer. Actual users of computer and internet in overall people of Bangladesh is less than these percentages.

\section{Calculation}

E-Banking is a new concept in banking sector of Bangladesh. It is becoming popular in Bangladesh; thus almost all Bangladeshi banks offer many facilities of ebanking. E-banking is growing in Bangladesh day by day. Customers can withdraw and deposit money any time within 24 hours of a day. All types of e-banking services are being appreciated and applied by people of different walks as this eases the activities. So, if an attractive offer package provided by the government e-banking will be popular everywhere very soon. If necessary initiative can be taken like improvement of quality of e-banking service, reducing financial insecurities, reducing unemployment problem by creating IT base job for technical experts, reducing tax on ebanking equipment, close monitoring, legal provisions for controlling frauds and malpractices etc. e-banking practices will increase and more positive impact will go on the banking sector in Bangladesh. As a result, economy of Bangladesh will be benefitted immensely.

\section{References}

[1] Sadekin M S and Shaikh A H (2015) "Current Status of EBanking Practices in Bangladesh." Scholar Journal of Business and Social Science, Vol.1

[2] Hossain M M, Irin D, Islam M S and Saha S (2013) "Electronic-Banking Services: A Study on Selected Commercial Banks in Bangladesh" Asian Business Review, Volume 3, Number
[3] Al-Amin S and Rahman S (2010) "Application of Electronic Banking in Bangladesh; An Overview" Bangladesh Research Publication Journal, Voliume-4

[4] Baten M A and Kamil A A (2010) "E-Banking of Economical Prospects in Bangladesh." Journal of Internet Banking and Commerce. V-15

[5] Bahl S (2012) "E-Banking: Challenges \& Policy Implications." International Journal Of Computing \& Business Research

[6] Leow, H B (1999) New Distribution Channels in banking Services. Bankers Journal Malaysia, No. 110

[7] Islam M M (2005) "Proposed ICT infrastructure for Ebanking in Bangladesh" Royal Institute of Technology (KTH), Department of Computer and Systems Sciences (DSV), Stockholm, Sweden

[8] Jalal A, Marzooq J, Nabi H A (2011) "Evaluating the Impacts of Online Banking Factors on Motivating the Process of Ebanking" Journal of Management and Sustainability

[9] Sadekin M S and Shaikh A H (2016) "Security of E-Banking in Bangladesh" Journal of Finance and Accounting

[10] Al Nahian Riyadh, Md. Shahriar Akter, Nayeema Islam (2009) "The Adoption of E-banking in Developing Countries: A Theoretical Model for SMEs" International Review of Business Research Papers

[11] Hasan A. H. M. S, Baten M A, Kamil A A, Parveen S ( 2010) "Adoption of e-banking in Bangladesh: An exploratory study" African Journal of Business Management

[12] Khan W, Kamruzzaman M (2012) "Problems and Prospects of E-Banking In Bangladesh" Development Compilation, Vol. 07. No. 02

[13] Ali M M (2010) "E-business and on-line banking in Bangladesh: an analysis" Banks and Bank Systems, Volume 5, Issue 2 